\title{
Effects of Inter- and Intra-Row Spacing on Growth, Green Cob Number and Biomass Yield of Maize (Zea mays L.) Varieties at Agarfa, Southeastern Ethiopia
}

\author{
Asfaw Shaka ${ }^{1} \quad$ Ketema Belete ${ }^{2} \quad$ Habtamu Zeleke ${ }^{3}$ \\ 1.College of Agriculture and Veterinary Sciences, Department of Horticulture, Ambo University, P.O box 19, \\ Ambo, Ethiopia \\ 2. College of Agriculture and Environmental Science, Department of Plant Sciences, Haramaya University, \\ P.O box 138, Dire Dawa, Ethiopia
}

\begin{abstract}
Maize (Zea mays L.) is an important grain crop of the world and it ranks second, after wheat in hectarage and first in total production and productivity. In Ethiopia, maize has increasingly become a popular crop with steady growth in production area and yield. However, green cob maize production packages, including its appropriate spacing, are not yet determined. Evidences on effects of inter and intra-row spacing on growth and green cob yield of maize are not well explored. Therefore, this study was conducted at Agarfa from March 2015 to July 2015 to determine the effects of inter-and intra-row spacing on growth, green cob number and biomass yield of maize (Zea mays L) varieties under supplemental irrigation. The experiment was laid out in a randomized complete block design with factorial combination of four inter-row $(55 \mathrm{~cm}, 65 \mathrm{~cm}, 75 \mathrm{~cm}$, and $85 \mathrm{~cm})$ spacing, two intra-row spacing $(25 \mathrm{~cm}$ and $30 \mathrm{~cm}$ ) and two maize varieties (Melkassa-II and BHQPY-545) with three replication. Data were collected on growth, green cob number and biomass yield and analyzed using GenStat, (2012) The experiment result revealed that leaf area and number of cobs per plant were highly significantly $(\mathrm{P}<0.01)$ affected by inter-row spacing $\mathrm{x}$ variety while cob length, number of cobs per hectare and above ground fresh biomass yield were significantly $(\mathrm{P}<0.05)$ affected by inter-row spacing $\mathrm{x}$ variety. The highest cob number $\left(65232.32 \mathrm{ha}^{-1}\right)$ was recorded for variety BHQPY-545 and $\left(61739.39 \mathrm{ha}^{-1}\right)$ for variety Melkassa-II at narrowest inter-row spacing of $55 \mathrm{~cm}$ (Table 5). Similarly, the highest fresh biomass yield of 51.3 and 48 ton ha ${ }^{-1}$ was obtained from variety BHQPY-545 and Melkassa-II respectively at $55 \mathrm{~cm}$ inter-row spacing. In general, significantly higher number of marketable green cobs and aboveground fresh biomass yield were obtained at closer inter-and intra-row spacing for maize varieties tested in the study area. Therefore, it can be concluded that spacing combination of $55 \mathrm{~cm} \times 25 \mathrm{~cm}$ favored attaining of higher economic returns, green cob number and fresh biomass yield of maize in the area under supplemental irrigation.
\end{abstract}

Keywords: Phenology, Plant Density, Population, Economic Benefit, Biomass

DOI: $10.7176 / \mathrm{JBAH} / 9-9-05$

Publication date:May $31^{\text {st }} 2019$

\section{Introduction}

Maize (Zea mays L.) is an important grain crop of the world and it ranks second, after wheat in hectarage $(187,959,116 \mathrm{ha})$ and first in total production $(1,060,107,470 \mathrm{MT})$ and productivity $(5.64 \mathrm{t}$ ha-1) (FAOSTAT, 2016). The advantages of maize in ethanol industry also keep it in high demand among other cereal crops. Rosegrant et al., (2010) reported that maize consumption by human in many developing and developed countries is steadily increasing though much of the world maize production is utilized for animal feed.

In Ethiopia, maize has increasingly become a popular crop in the country with steady growth in production area and yield (Doss et al., 2003). It is Ethiopia's leading cereal in produced in by about 10.9 million farmers across about 2.1 million hectares of land in 2017Meher season (CSA, 2017).

Agarfa district, where the study was conducted, is one of maize producing districts in Bale Zone. Maize is the $3^{\text {rd }}$ cereal crop in production next to wheat and barley in the area. According to CSA, (2017) 108384.8 ton of maize was produced on about 33951 ha of land during 2017 in Meher season with yield of 3.2 ton ha ${ }^{-1}$. In the area, the production of maize under supplemental irrigation takes on a special significance; because there is high demand for green maize consumption during off season as long as water is available for irrigation and production can be carried out during the off season. As it is grown as green cob in the area, maize is important food and income sources for many farmers (BoA of Agarfa district, 2015).

As compared to other cereals; maize can attain the highest potential yield per unit area. World average yield for maize is about $4.5 \mathrm{t} \mathrm{ha}^{-1}$ and that of developed countries is $6.2 \mathrm{tha}^{-1}$ while the average yield in developing countries is $2.5 \mathrm{t} \mathrm{ha}^{-1}$. In Ethiopia the national average yield is about $3.68 \mathrm{t} \mathrm{ha}^{-1}$ (CSA, 2017). Although significant gains have been made in maize production over the past decades, there remains large potential to increase productivity.

The majority of smallholder farmers in Ethiopia are aware of the benefits of adopting input technologies to 
enhance their maize productivities. However, this awareness is mainly about some improved varieties, commonly used fertilizers like Urea and DAP while the knowledge about micro-nutrients and recommended agronomic packages like optimum plant density are almost not sufficient. Likewise, there is much room for improvement in getting farmers adopt and implement the recommended package of agronomic management methods including proper land preparation and tillage, row planting, maintaining the right planting depth, plant population, time and frequency of weeding and proper time of harvesting (ATA, 2013).

Three production variables that a producer can manipulate to influence the production of a given crop are plant population, row arrangement and hybrid selection (Zaffaroni and Schneiter, 1991). Optimum inter- and intra-row spacing varies with soil fertility status, soil moisture, the nature of the crop and degree of weed infestation (Singh et al., 1997).

Though, most of appropriate agronomic practices and requirements of maize have been studied and determined for grain production, there is limited information on plant population and row arrangement for green cob maize production according to different situations like height and maturity period of variety, soil fertility status etc. Hence, realizing the importance of developing appropriate cultural practices such as plant spacing for optimum production of maize as green cob in Agarfa district under supplemental irrigation, this study was envisaged.

Most of the maize producing farmers in Agarfa district do not use the national recommendation and they have been using narrower spacing ranging 55-65 inter-row spacing and 25-30 intra-row spacing (Personal observation). This variation in spacing needs to be evaluated with the recommended $75 \times 30 \mathrm{~cm}$ with that of farmers practice. Objectives of this study, therefore, was to investigate the effects of inter-and intra-row spacing on growth, green cob number and biomass yield of maize varieties; and to determine economically optimum inter- and intra- row spacing to achieve higher number of green cob per hectare in the study area.

\section{Materials and methods}

\subsection{Description of the study area}

The study was conducted under rain-fed condition supplemented with irrigation during 2015 cropping season at Agarfa ATVET College demonstration site, southeast Ethiopia. The experimental site is located at $458 \mathrm{~km}$ away from Addis Ababa and $30 \mathrm{~km}$ from Bale Robe city. The site is found at an altitude of $2330 \mathrm{~m}$.a.s.1 level with mean maximum and mean minimum temperature of $24.75{ }^{\circ} \mathrm{C}$ and $7.1{ }^{\circ} \mathrm{C}$ respectively. The area receives the average annual rainfall of $829.4 \mathrm{~mm}$ (BoA of Agarfa district, 2015).

\subsection{Description of Experimental Materials}

Two maize varieties, namely Melkassa-II and BHQPY-545 were used in the experiment. Melkassa-II is an improved variety which was released in 2003 performing well in agro-ecological range of 1000-1700m.a.s.1 with rainfall range of $600-800 \mathrm{~mm}$. It can give $4500-5500$ and $3000-4000 \mathrm{~kg}$ grain yields per hectare in on-station and on farm experiments, respectively. It is moderately tolerant to disease and lodging (EARO, 2004). 'BHQPY$545^{\prime}$ is an early maturing variety adapted to low-mid altitude (1000-1800 masl) areas with high protein. It was released in the year 2008 and its yield potential is 8-10 $\mathrm{t} \mathrm{ha}^{-1}$ (EIAR, 2008). Variety Melkassa-II is open pollinated and BHQPY-545 is hybrid. Diammonium phosphate (DAP) and Urea fertilizers were used as a source of phosphorous and nitrogen.

\subsection{Treatments and Experimental Design.}

The treatment consisted of factorial combination of four inter-row spacing $(55 \mathrm{~cm}, 65 \mathrm{~cm}, 75 \mathrm{~cm}$ and $85 \mathrm{~cm})$, and two intra-row spacing $(25 \mathrm{~cm}$ and $30 \mathrm{~cm})$ using two maize varieties (Melkassa-II and BHQPY-545). The experiment was laid out in randomized complete block design (RCBD) in factorial arrangement with three replications. There were 4, 5, 6 and 7 rows for $85,75,65$ and $55 \mathrm{~cm}$ row spacing respectively. The blocks were separated from each other by a $1.5 \mathrm{~m}$ wide space and the distance between each plot was $1 \mathrm{~m}$. The gross plot size was $4.5 \times 3.90\left(17.55 \mathrm{~m}^{2}\right)$ accommodating $7,6,5$, and 4 rows for 55, 65, 75 and $85 \mathrm{~cm}$ inter-rows respectively. The net plot size for $55,65,75$ and $85 \mathrm{~cm}$ was $10.725 \mathrm{~m}^{2}\left(5^{*} 0.55 \mathrm{mx} 3.90 \mathrm{~m}\right), 10.14 \mathrm{~m}^{2}\left(4^{*} 0.65 \mathrm{mx} 3.90 \mathrm{~m}\right), 8.775$ $\mathrm{m}^{2}(3 * 0.75 \mathrm{mx} 3.90 \mathrm{~m})$ and $6.63 \mathrm{~m}^{2}(2 * 0.85 \mathrm{mx} 3.90 \mathrm{~m})$ respectively. The central rows left aside for data recording were $5,4,3$, and 2 rows for $55,65,75$, and $85 \mathrm{~cm}$ inter-row spacing, respectively.

\subsection{Management of the Experimental Field}

Prior to sowing, the land was well prepared by repeated ploughing using oxen plough. Maize seeds were planted as per proposed inter and intra-row spacing. Initially two seeds per hill were planted and latter thinned to one plant at the stage of 3 to 4 leaves. At time of planting, all plots were received a basal application $\mathrm{N}$ and $\mathrm{P}_{2} \mathrm{O}_{5}$ at the rate of $18 \mathrm{~kg} \mathrm{~N} \mathrm{ha}^{-1}$ and $46 \mathrm{~kg} \mathrm{P}_{2} \mathrm{O}_{5} \mathrm{ha}^{-1}$ in the form of diammonium phosphate (DAP). In addition all plots were top dressed with $23 \mathrm{~kg} \mathrm{~N} \mathrm{ha}^{-1}$ at knee height and $23 \mathrm{~kg} \mathrm{~N} \mathrm{ha}^{-1}$ at boot stage. All other agronomic and cultural practices like hoeing, weeding, etc were applied to all treatments as per recommended. 


\subsection{Economic Analysis}

Mean cob and fresh biomass yields of the treatments were used in partial budget analysis using CIMMYT, (1988). The field price that farmers receive from the sale of one cob and 1 ton of fresh biomass of maize respectively was taken as 3 Birr and 500 Birr base on the market price of maize at Agarfa town, near the experimental site, $449 \mathrm{~km}$ from Addis Ababa. The green cob number and fresh biomass yield was adjusted by $10 \%$ and gross benefit was calculated as $10 \%$ adjusted green cob number and fresh biomass yield ha ${ }^{-1}$ multiplied by field price that farmers receive for the sale of one cob and $1 \mathrm{~kg}$ of fresh biomass.

Dominance analysis: was carried out by first listing all the treatments in their order of increasing costs that vary (TVC) and their net benefits (NB) are then put aside. Any treatment that has higher TVC but net benefits that are less than or equal to the preceding treatment (with lower TVC but higher net benefits) is dominated treatment (marked as "D").

Marginal rate of return (MRR) (\%): was calculated by dividing change in net benefit $(\Delta \mathrm{NB})$ by change in total variable costs $(\triangle \mathrm{TVC})$ and then multiplied by 100 .

\subsection{Crop Data Collected}

Samples were taken randomly from the central rows and data on crop phenology (days to $50 \%$ tasseling, days to $50 \%$ silking and days to late milk stage) were recorded at their respective stages. Leaf area at $50 \%$ silking, leaf area index (LAI), plant height, stand count percent, number of ears per plant, number of cob per net plot, number of cob per hectare, cob length, cob weight, and above ground fresh biomass yield were collected.

\subsection{Statistical Data Analysis}

The measured variables were analyzed using Statistical Soft ware (GenStat, 2012) as per the model described for randomized complete block design. Effects were considered significant if $\mathrm{P}$ values are $<0.05$. Significance difference among treatment means were compared using LSD at 5\% level of significance (Gomez and Gomez, 1984).

\section{Results and Discussion}

\subsection{Crop Phenology}

The main effects of inter-,intra-row spacing and variety as well as the interaction of inter-row, intra-row spacing and variety did not affect significantly days to $50 \%$ tasseling, days to $50 \%$ silking and days to late milk stage (Appendix Table 1). The present result agree with that of Gozubenli (2004) who reported that the effect of interand intra-row spacing did not significantly affect days to tasseling and maturity. Similarly, Zenebe (2004) reported that the effect of plant population was not significant on days to $50 \%$ flowering and days to $90 \%$ maturity of sorghum.

\subsection{Growth Parameters}

\subsubsection{Plant height}

The main effects of inter-row spacing and variety and inter-row $\mathrm{x}$ variety showed highly significant $(\mathrm{P}<0.01)$ effects and interaction of inter-row spacing, intra-row spacing and variety showed significant $(\mathrm{P}<0.05)$ effect on plant height (Appendix Table 2). The variety BHQPY-545 gave the highest plant height $(289.9 \mathrm{~cm})$ at narrowest spacing of $55 \times 25 \mathrm{~cm}$ although the difference statistically not significant with that of $55 \mathrm{~cm} \times 30 \mathrm{~cm}$ while the variety Melkassa-II gave the lowest $(223.2 \mathrm{~cm})$ at the widest spacing of $85 \times 30 \mathrm{~cm}$.

Generally, plant height increased with decrease in inter-row and intra-row spacing. When the inter-row spacing was decreased from 85 to $55 \mathrm{~cm}$ and intra-row spacing from $30 \mathrm{~cm}$ to $25 \mathrm{~cm}$, plant height was increased from $223.2 \mathrm{~cm}$ to $261.7 \mathrm{~cm}$ for Melkassa-II and $272.6 \mathrm{~cm}$ to $289.9 \mathrm{~cm}$ for BHQPY-545 (Table 1).

Table 1. Interaction effects of inter-row, intra-row spacing and variety on plant height of maize $(\mathrm{cm})$

\begin{tabular}{lllll}
\hline \multirow{2}{*}{ Treatments } & \multicolumn{3}{c}{ Melkassa-II } & \multicolumn{2}{c}{ BHQPY-545 } \\
\cline { 2 - 5 } Inter-row spacing $(\mathrm{cm})$ & 25 & 30 & 25 & 30 \\
\cline { 2 - 5 } & $261.7^{\mathrm{e}}$ & $257.0^{\mathrm{f}}$ & $289.9^{\mathrm{a}}$ & $288.8^{\mathrm{ab}}$ \\
65 & $247.5^{\mathrm{h}}$ & $252.6^{\mathrm{g}}$ & $285.4^{\mathrm{b}}$ & $285.3^{\mathrm{b}}$ \\
75 & $243.9^{\mathrm{h}}$ & $247.1^{\mathrm{h}}$ & $279.9^{\mathrm{c}}$ & $275.3^{\mathrm{d}}$ \\
85 & $239.1^{\mathrm{i}}$ & $223.2^{\mathrm{j}}$ & $273.7^{\mathrm{d}}$ & $272.6^{\mathrm{g}}$ \\
\hline \multicolumn{5}{c}{ LSD $(0.05)=8.687$} \\
\hline \multicolumn{5}{c}{ CV $(\%)=2.0$} \\
\hline
\end{tabular}

Where, LSD (0.05) $=$ Least Significant Difference at $5 \%$ level; NS=Non-Significant; CV=Coefficient of Variation. Means in rows and column followed by the same letters are not significantly different at $5 \%$ level of significance.

The increase in the plant height of maize varieties at narrowest inter-row and intra-row spacing (higher 
plant densities) may be due to strong competition among the plants for light and mutual shading. This result agrees with the finding of Raouf et al., (2009) who reported that the plant height significantly increased with the increase in plant densities in maize hybrids.

\subsubsection{Leaf area}

The analysis of variance showed that leaf area was highly significantly $(\mathrm{P}<0.01)$ affected by the main effect of inter-row spacing, variety and inter-row $\mathrm{x}$ variety, but intra-row spacing and all other interaction did not significantly affect LA (Appendix Table 2).

The highest leaf area $\left(7637.33 \mathrm{~cm}^{2}\right)$ was recorded at inter-row spacing of $85 \mathrm{~cm}$ for variety BHQPY-545 while the lowest leaf area $\left(6076 \mathrm{~cm}^{2}\right)$ was recorded at inter-row spacing of $55 \mathrm{~cm}$ for variety Melkassa-II (Table 4).

Table 2. Effects of inter-row spacing x variety on leaf area of maize $\left(\mathrm{cm}^{2}\right)$

\begin{tabular}{lll}
\hline \multicolumn{3}{l}{ Maize Varieties } \\
\hline Inter-row spacing $(\mathrm{cm})$ & Melkassa-II & BHQPY-545 \\
55 & $6076.00^{\mathrm{e}}$ & $6522.67^{\mathrm{d}}$ \\
65 & $6231.67^{\mathrm{e}}$ & $7116.67^{\mathrm{b}}$ \\
75 & $6449.50^{\mathrm{d}}$ & $7510.33^{\mathrm{a}}$ \\
85 & $6826.33^{\mathrm{c}}$ & $7637.33^{\mathrm{a}}$ \\
\hline \multicolumn{3}{c}{$\operatorname{LSD}(0.05)=209.740$} \\
\hline
\end{tabular}

Where, LSD (0.05) =Least Significant Difference at 5\% level; NS=Non-Significant; CV=Coefficient of Variation. Means in column followed by the same letters are not significantly different at $5 \%$ level of significance.

Increasing inter-row spacing from $55 \mathrm{~cm}$ to $85 \mathrm{~cm}$ increased the leaf area in $10.99 \%$ and $14.59 \%$ for variety Melkassa-II and BHQPY-545 respectively and the increment was consistent.

The reduced leaf area with narrow inter-row spacing for the two maize varieties might be due to high competition for assimilates at higher plant density, hence less average leaf area per plant. This is in agreement with Enujeke, (2013) who reported that the interactions of variety and inter-row spacing showed significant effect and positively affected leaf area of maize.

\subsection{Cob yield and yield components of maize}

\subsubsection{Plant stand count percent}

The analysis of variance showed that there were highly significant $(\mathrm{P}<0.01)$ effect on stand count percent due to main effect of inter-row spacing, intra-row spacing and variety and their interactions showed significant $(\mathrm{P}<0.05)$ effect on stand count percentage (Appendix Table 3 ).

The highest stand count of $97.37 \%$ and the lowest stand count of $89.53 \%$ were recorded at inter-row and intra-row spacing of $85 \mathrm{~cm}$ x $30 \mathrm{~cm}$ and $55 \mathrm{~cm}$ x $25 \mathrm{~cm}$ respectively for variety BHQPY-54 (Table 3). In general, plant stand percent of maize varieties decreased with reduced inter-and intra-row spacing (as plant population increased) and that might be due to crowding effect. There is a possibility that at narrowest inter- and intra-row spacing (with higher population density) smaller plants crowded out and disappeared. At lower population comparatively, availability of more space might have resulted in less competition for resources (nutrients, moisture and light) whereas at high density due to more intra-specific competition the weaker plants might have died by the time the crop approached maturity.

The result indicated that variety BHQPY-545 is comparatively sensitive to higher plant density than variety Melkassa-II. The variation in stand count percentage between the two maize varieties tested might be due to genetic variability, better utilization of resources like space, air, water and nutrients.

This result is in agreement with the findings of Ahmad et al., (2012) who reported that both plant population density and variety showed significant difference in final plant population of maize. 
Table 3. Interaction effects of inter-row spacing, intra-row spacing and variety on Stand Count percentage of Maize

\begin{tabular}{lllll}
\hline \multirow{2}{*}{ Treatments } & \multicolumn{2}{l}{ Melkassa-II } & \multicolumn{2}{l}{ BHQPY-545 } \\
\cline { 2 - 5 } Inter-row spacing $(\mathrm{cm})$ & \multicolumn{2}{l}{ Intra-row spacing $(\mathrm{cm})$} & 25 & 30 \\
\cline { 2 - 5 } & 25 & $90.40^{\mathrm{fg}}$ & $89.53^{\mathrm{g}}$ & $94.73^{\mathrm{bcd}}$ \\
65 & $89.87^{\mathrm{g}}$ & $93.67^{\mathrm{de}}$ & $94.13^{\text {cde }}$ & $95.60^{\mathrm{abcd}}$ \\
75 & $92.23^{\mathrm{ef}}$ & $95.60 \mathrm{abcd}$ & $97.07^{\mathrm{a}}$ & $96.23^{\mathrm{abc}}$ \\
85 & $94.47^{\mathrm{cde}}$ & $96.77^{\mathrm{ab}}$ & $96.00^{\mathrm{abc}}$ & $97.37^{\mathrm{a}}$ \\
\hline \multicolumn{5}{c}{} \\
\hline \multicolumn{5}{c}{ LSD $(0.05)=2.255$} \\
\hline
\end{tabular}

Where, LSD (0.05) $=$ Least Significant Difference at $5 \%$ level; CV=Coefficient of Variation. Means in rows and column followed by the same letters are not significantly different at $5 \%$ level of significance.

This result was also in line with that of Sangoi et al., (2001) who reported that wider inter- and intra-row spacing of $75 \mathrm{~cm} \times 26.6 \mathrm{~cm}$ had greater plant stand count percent of maize as compared to the initial count than that of narrow inter- and intra-row spacing of $50 \mathrm{~cm}$ x $17.7 \mathrm{~cm}$. Similarly, Eskandarnejada et al., (2013) reported that higher plant stand count percent was achieved due to the wider spacing combinations of $75 \mathrm{~cm} \times 30 \mathrm{~cm}$ than narrower spacing of $55 \mathrm{~cm} \times 20 \mathrm{~cm}$.

\subsubsection{Cob length}

The main effect of inter-row spacing and variety showed highly significant $(\mathrm{P}<0.01)$ effect and inter-row spacing $\mathrm{x}$ variety showed significant $(\mathrm{P}<0.05)$ effect while the main effect of intra-row spacing and all other interaction did not show significant effect on cob length (Appendix Table 3).

Statistical analysis result showed that the increase in cob length became progressively smaller as planting density increased (Table 4$)$. The highest cob length $(29.47 \mathrm{~cm})$ was recorded at $75 \mathrm{~cm}$ for variety BHQPY-545 while lowest cob length (20.23) was recorded at $55 \mathrm{~cm}$ for variety Melkassa-II (Table 6). This indicates that unhusked marketable cob length of maize decreased linearly and similarly in both varieties as inter-row spacing decreased and planting density increased. This is in agreement with observation by Bavec and Bavec (2002).

Maize variety BHQPY-545 was superior to the other variety with regard to cob length at all planting densities. The difference in relation to planting density effects on cob length is certainly due to environmental factors and characteristics of the evaluated varieties.

This result is also in line with finding of Enujeke, (2013) who reported that spacing x variety were significantly affected cob length of maize.

Table 4. Effects of inter-row spacing $\mathrm{x}$ variety on cob length of maize $(\mathrm{cm})$

\begin{tabular}{lll}
\hline & \multicolumn{2}{c}{ Maize Varieties } \\
\hline Inter-row spacing $(\mathrm{cm})$ & $20.23^{\mathrm{f}}$ & BHQPY-545 \\
55 & $21.58^{\mathrm{e}}$ & $25.57^{\mathrm{d}}$ \\
65 & $23.10^{\mathrm{d}}$ & $27.60^{\mathrm{c}}$ \\
75 & $24.47^{\mathrm{c}}$ & $29.47^{\mathrm{b}}$ \\
85 & \multicolumn{3}{c}{$\operatorname{LSD}(0.05)=1.303$} \\
\hline \multicolumn{3}{c}{$\mathrm{CV}(\%)=4.4$} \\
\hline \multicolumn{3}{c}{}
\end{tabular}

Where, LSD (0.05) =Least Significant Difference at 5\% level; CV=Coefficient of Variation. Means in column followed by the same letters are not significantly different at $5 \%$ level of significance.

\subsubsection{Number of cobs per plant}

Analysis of variance showed that main effects of inter-row spacing and variety and inter-row spacing $\mathrm{x}$ variety had highly significant $(\mathrm{P}<0.01)$ effect on number of cobs per plant while the main effect of intra-row spacing and all other interaction effect did not show significant effect (Appendix Table 4).

This result is in line with the finding of Enujeke, (2013) who reported that interaction of spacing and variety was significantly affected the number of cob/plants.

Significantly lowest number of cobs per plant (1.03) was recorded at the narrowest spacing of $55 \mathrm{~cm}$ for variety Melkassa-II while significantly highest number of cobs (1.42) was recorded at the widest spacing of 85 $\mathrm{cm}$ for variety BHQPY-545 (Table 5). Inter-row spacing of $55 \mathrm{~cm}, 65 \mathrm{~cm}$ and $75 \mathrm{~cm}$ did not show statistically difference tough there were numerical differences.

In general, number of cobs per plant was decreased as inter-row spacing decreased for both varieties. The decrease in number of cobs per plant with decrease in plant inter-row spacing for the maize varieties could be due to increased intra specific competition which eventually caused reduction in number of cobs per plant. In contrast, the increase in the number of cobs per plant with increased inter-row spacing might be due to higher net assimilation rate of the maize varieties and partitioning and reduction of competition in wider spacing. 
Ahmad et al., (2006) reported that the highest number of ears per plant in maize crop sown in $75 \mathrm{~cm}$ spaced rows than crop grown at $55 \mathrm{~cm}$ and $45 \mathrm{~cm}$. This is similar to the findings of Kim, (1997) and Olakojo et al., (1993) who reported that highest number of cobs yield were obtained from higher plant density due to narrow spacing.

\subsubsection{Number of cobs per hectare}

Analysis of variance indicated that the main effects of inter-row spacing and variety had highly significant $(\mathrm{P}<0.01)$ and inter-row spacing $\mathrm{x}$ variety had significant $(\mathrm{P}<0.05)$ effect on number of cobs per hectare while the main effects of intra-row spacing and all other interaction effects did not show significant effects (Appendix Table 4).

Significantly the lowest number of cobs per hectare (47738.95) was recorded at widest inter-row spacing of $85 \mathrm{~cm}$ for variety Melkassa-II while the highest cob number of 65232.32 for variety BHQPY-545 and 61739.39 cobs per hectare for variety Melkassa-II was recorded at narrowest inter-row spacing of $55 \mathrm{~cm}$ (Table 5). This agrees with the finding of Raja, (2001) who reported that rising of corn plant population from 53333 to 88888 plants per hectare significantly increased the fresh ear yield.

Regarding the number of cobs per hectare recorded, both maize varieties (BHQPY-545 and Melkassa-II) gave the highest number of cobs ha ${ }^{-1}$ at the narrower inter-row spacing of $55 \mathrm{~cm}$. Computing the differences between the two maize varieties in number green cobs recorded per hectare, BHQPY-545 gave statistically higher number of cobs than Melkassa-II at inter-row spacing of 65,75 and $85 \mathrm{~cm}$. This could be attributed to genetic differences that exist between maize varieties with respect to yield, and its components and ability to combine traits between maize cultivars as response to plant density. This is similar to finding of Odeleye and Odeleye (2001) who reported maize varieties differ in their growth characteristics, yield and its components and therefore suggested that breeders must select most promising varieties which have the ability to combine good traits in their breeding programs.

\subsubsection{Above ground fresh biomass}

Analysis of variance indicated that main effect of inter-row spacing and variety had highly significant $(\mathrm{P}<0.01)$ and inter-row spacing $\mathrm{x}$ variety had significant $(\mathrm{P}<0.05)$ effect on above ground fresh biomass, while the main effect of intra-row spacing and all other interaction effect did not show significant effect.(Appendix Table 4).

Statistically highest fresh biomass yield of 51.3 and 48 ton $\mathrm{ha}^{-1}$ was obtained at $55 \mathrm{~cm}$ inter-row spacing for variety BHQPY-545 and Melkassa-II respectively while the lowest above ground fresh biomass yield of 33.2 ton $\mathrm{ha}^{-1}$ was obtained at wider row spacing of $85 \mathrm{~cm}$ for variety Melkassa-II (Table 5). In general, fresh biomass yield was increased with decreased inter-row spacing for both maize varieties. The increases in above ground fresh biomass yield with lower inter-row spacing (higher plant densities) could be due to more number of plants in per unit area of land for both varieties.

There was significant difference of above ground fresh biomass yield between the two maize varieties at widest inter-row spacing and variety BHQPY-545 was performed better as compared variety Melkassa-II. Although the difference was statistically not significant at the inter-row spacing of $55 \mathrm{~cm}$, variety BHQPY-545 gave significantly higher biomass as at inter-row spacing of 65,75 and $85 \mathrm{~cm}$ as compared with variety Melkassa-II. This result agrees the finding of Tolera et al., (1999) who suggested that breeders should select maize varieties that combine high yield with desirable stover characteristics because of the large differences that exist between cultivars.

This result is also in line with the finding of Dicu et al., (2016) who reported that the lowest fresh biomass yield of 30.7 tons $\mathrm{ha}^{-1}$ was obtained at row spacing of $75 \mathrm{~cm}$ (at plant density of 100,000 plants.ha $^{-1}$ ) while the highest fresh biomass yield of 32.5 tons ha $^{-1}$ was obtained at row spacing of $37.5 \mathrm{~cm}$ (plant density of 120,000 plants $\mathrm{ha}^{-1}$ ) for two maize hybrids tested. Similarly, Aslam et al., (2011) reported that dry matter accumulation was much in high plant densities compared to low plant densities. 
Table 5. Effects of inter-row spacing $\mathrm{x}$ variety on number of cobs per plant, number of cobs per hectare and above ground fresh biomass (ton $\mathrm{ha}^{-1}$ ) of maize

\begin{tabular}{|c|c|c|c|c|c|c|}
\hline \multirow[t]{3}{*}{ Treatments } & \multicolumn{6}{|c|}{ Maize Varieties } \\
\hline & \multicolumn{3}{|c|}{ Melkassa-II } & \multicolumn{3}{|c|}{ BHQPY-545 } \\
\hline & NCPP & $\mathrm{NCPH}$ & $\begin{array}{l}\text { AGFB } \\
\text { (ton/ha) }\end{array}$ & NCPP & $\mathrm{NCPH}$ & $\begin{array}{l}\text { AGFB } \\
\text { (ton/ha) }\end{array}$ \\
\hline \multicolumn{7}{|l|}{$\begin{array}{l}\text { Inter-row } \\
\text { spacing }(\mathrm{cm})\end{array}$} \\
\hline 55 & $1.03^{\mathrm{d}}$ & $61739.39 b^{\mathrm{abc}}$ & $48.0^{\mathrm{ab}}$ & $1.07^{\mathrm{cd}}$ & $65232.32^{\mathrm{a}}$ & $51.3^{\mathrm{a}}$ \\
\hline 65 & $1.10^{\mathrm{bcd}}$ & $57493.68^{c}$ & $43.6^{\mathrm{d}}$ & $1.18^{\mathrm{b}}$ & $63052.99^{\mathrm{ab}}$ & $48.9^{\mathrm{ab}}$ \\
\hline 75 & $1.10^{\mathrm{bcd}}$ & $49924.52^{\mathrm{d}}$ & $38.4^{\mathrm{e}}$ & $1.33^{\mathrm{a}}$ & $61452.89^{a b c}$ & $47.1^{\mathrm{bc}}$ \\
\hline 85 & $1.15^{\mathrm{bc}}$ & $47738.95^{\mathrm{d}}$ & $33.2^{\mathrm{f}}$ & $1.42^{\mathrm{a}}$ & $59000.13^{\mathrm{bc}}$ & $44.2^{\mathrm{cd}}$ \\
\hline LSD (0.05) & 0.086 & 4365.591 & 3.32 & 0.086 & 4365.591 & 3.32 \\
\hline $\mathrm{CV}(\%)$ & 6.2 & 6.4 & 6.4 & 6.2 & 6.4 & 6.4 \\
\hline
\end{tabular}

Where, LSD (0.05) =Least Significant Difference at 5\% level; NS=Non-Significant; NCPP=Number of Cobs per Plant; NCPH=Number of Cobs per Hectare; AGFB=Above Ground Fresh Biomass; $\mathrm{CV}=$ Coefficient of Variation. Means in column followed by the same letters are not significantly different at $5 \%$ level of significance.

\subsection{Economic Analysis}

To assess the cost benefit related to different treatments, the partial budget analysis techniques of CIMMYT (1988) was applied. From the partial budget analysis summary (Table 6), the highest net return of 197788.64 with an acceptable marginal return rate of $4086.04 \%$ and 192081.35 Birr ha $^{-1}$ with an acceptable marginal return rate of 25961.41\% was obtained for variety BHQPY-545 and Melkassa-II respectively from spacing combinations of $55 \mathrm{~cm} \times 25 \mathrm{~cm}\left(72727\right.$ plants $\left.\mathrm{ha}^{-1}\right)$ followed by $65 \mathrm{~cm}$ x $25 \mathrm{~cm}$ spacing combinations (61538

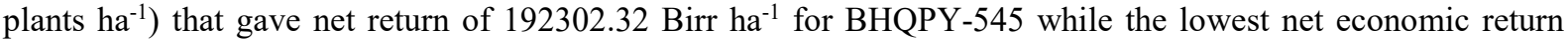
was obtained at the spacing combinations of $85 \mathrm{~cm} \mathrm{x} 30 \mathrm{~cm}$ (39215 plants ha $\left.{ }^{-1}\right)$ for both varieties ( Table 6).This indicates that for both maize varieties, $55 \times 25 \mathrm{~cm}$ gave the highest and $85 \mathrm{~cm}$ x $30 \mathrm{~cm}$ the lowest economic return.

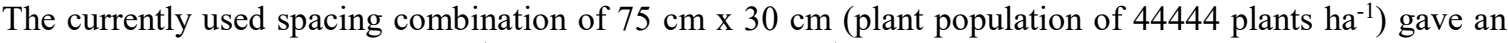
economic return of 136190.95 Birr ha $^{-1}$ and 171771.66 Birr ha ${ }^{-1}$ for Melkassa-II and BHQPY-545 respectively. Thus, the use of $55 \mathrm{~cm}$ inter-row spacing with $25 \mathrm{~cm}$ intra-row spacing (72727 plants ha ${ }^{-1}$ ) resulted in $29.1 \%$ economic return increments to Melkassa-II and 13.15\% increment to BHQPY-545 maize variety than economic return from that of the currently used inter- and intra-row spacing of $75 \mathrm{~cm} \mathrm{x} 30 \mathrm{~cm}\left(44444\right.$ plants ha $\left.^{-1}\right)$. Thus, using inter-row spacing of $55 \mathrm{~cm}$ and intra-row spacing of $25 \mathrm{~cm}$ (72727 plants ha $\left.{ }^{-1}\right)$ resulted in higher increment to the number of green cob maize income from that of the currently used practice by the farmer's (44444 plants $\mathrm{ha}^{-1}$ ). This result is in line with the finding of Trinh et al., (2008) who obtained higher net economic benefit from higher planting density. 
Table 6. Partial budget analysis of inter-row and intra-row spacing on maize varieties

\begin{tabular}{|c|c|c|c|c|c|c|c|c|}
\hline Treatment & $\mathrm{ACY}$ & $\begin{array}{l}\text { AFBY } \\
\text { (ton/ha) }\end{array}$ & $\begin{array}{c}\text { CYR } \\
\text { (Birrr/ha) }\end{array}$ & $\begin{array}{c}\text { FBYR } \\
\text { (ton/ha) }\end{array}$ & $\begin{array}{c}\text { GR } \\
\text { (Birr/ha) }\end{array}$ & $\begin{array}{c}\text { TVC } \\
\text { (Birr/ha) }\end{array}$ & $\begin{array}{c}\text { NR } \\
\text { (Birr/ha) }\end{array}$ & MRR (\%) \\
\hline $\begin{array}{c}85 \mathrm{x} \\
30 \mathrm{xV} 1 \\
\end{array}$ & 39845.88 & 28.98 & 119537.64 & 14490 & 134027.64 & 9223.92 & 127403.72 & 1381.23 \\
\hline $\begin{array}{c}75 \mathrm{x} \\
30 \mathrm{xV} 1 \\
\end{array}$ & 42064.02 & 33.3 & 126192.06 & 16650 & 142842.06 & 9251.11 & 136190.95 & 32317.87 \\
\hline $\begin{array}{c}85 x \\
25 x V 1\end{array}$ & 46084.24 & 30.78 & 138252.72 & 15390 & 153642.72 & 9264.71 & 146978.01 & 79316.61 \\
\hline $\begin{array}{c}75 \mathrm{x} \\
25 \mathrm{xV} 1\end{array}$ & 47800.13 & 35.82 & 143400.4 & 17910 & 161310.4 & 9286.67 & 154613.07 & 23406.06 \\
\hline $\begin{array}{c}65 x \\
30 x V 1\end{array}$ & 48984.62 & 38.07 & 146953.85 & 19035 & 165988.85 & 9297.33 & $159302.18^{\mathrm{D}}$ & \\
\hline $\begin{array}{c}55 \mathrm{x} \\
30 \mathrm{xV} 1 \\
\end{array}$ & 52592.72 & 42.12 & 157778.17 & 21060 & 178838.17 & 9335.15 & 172103.02 & 26404.37 \\
\hline $\begin{array}{c}65 \mathrm{x} \\
25 \mathrm{xV} 1\end{array}$ & 54504 & 40.41 & 163512 & 20205 & 183717 & 9340.00 & 176977.00 & 100494.43 \\
\hline $\begin{array}{c}55 x \\
25 x V 1\end{array}$ & 58898.18 & 44.37 & 176694.53 & 22185 & 198879.53 & 9398.18 & 192081.35 & 25961.41 \\
\hline $\begin{array}{c}85 \mathrm{x} \\
30 \mathrm{xV} 2\end{array}$ & 49255.29 & 38.97 & 147765.87 & 19485 & 167250.87 & 9490.59 & 160360.28 & 1662.28 \\
\hline $\begin{array}{c}75 \times \\
30 x V 2\end{array}$ & 52600 & 41.85 & 157799.99 & 20925 & 178724.99 & 9553.33 & 171771.66 & 18188.34 \\
\hline $\begin{array}{c}85 \mathrm{x} \\
25 \mathrm{xV} 2 \\
\end{array}$ & 56944.94 & 40.59 & 170834.83 & 20295 & 191129.83 & 9584.71 & 184145.12 & 39431.10 \\
\hline $\begin{array}{c}65 \mathrm{x} \\
30 \mathrm{xV} 2\end{array}$ & 54418.46 & 43.65 & 163255.39 & 21825 & 185080.39 & 9635.38 & $178045.01^{\mathrm{D}}$ & \\
\hline $\begin{array}{c}75 x \\
25 x V 2\end{array}$ & 58015.2 & 43.02 & 174045.59 & 21510 & 195555.59 & 9660.00 & 188495.59 & 42447.52 \\
\hline $\begin{array}{c}55 \mathrm{x} \\
30 \mathrm{xV} 2\end{array}$ & 56872.73 & 45.54 & 170618.18 & 22770 & 193388.18 & 9747.27 & $186240.91^{\mathrm{D}}$ & \\
\hline $\begin{array}{c}65 \mathrm{x} \\
25 \mathrm{xV} 2\end{array}$ & 59076.93 & 44.46 & 177230.78 & 22230 & 199460.78 & 9758.46 & 192302.32 & 54168.09 \\
\hline $\begin{array}{c}55 x \\
25 x V 2\end{array}$ & 60545.46 & 46.89 & 181636.37 & 23445 & 205081.37 & 9892.73 & 197788.64 & 4086.03 \\
\hline
\end{tabular}

Where, IRS=Inter-Row Spacing; INRS=Intra-Row Spacing; V=Variety; V1=Variety 1 (Melkassa-II); V2=Varity 2 (BHQPY-545); ACY=Adjusted Cob Yield, AFBY=Adjusted Fresh Biomass Yield, CYR=Cob Yield Return, FBYR $=$ Fresh Biomass Yield Return, $\mathrm{GR}=$ Gross Return, NR=Net Return, TVC $=$ Total Variable Costs, $\mathrm{D}=$ Dominated Treatment

\section{SUMMARY AND CONCLUSION}

The results of the present study concluded that the highest green cob number and biomass yield was obtained at spacing combination of $55 \mathrm{~cm}$ inter row spacing and $25 \mathrm{~cm}$ intra row spacing for maize varieties tested in the area. Comparing the two maize varieties tested, BHQPY-545 maize variety was superior to Melkassa-II maize variety in most agronomic parameters and economic returns. Therefore, it can be recommended for use by farmers to produce BHQPY -545 maize variety with $55 \mathrm{~cm}$ x $25 \mathrm{~cm}$ spacing combinations for more profitable production of maize as green cob.

\section{REFERENCES}

Agarfa District Bearaue of Agriculture, annual report on crop production, 2015.

Ahmad, R., Tanveer A., Maqbool M.M., and Ata Z., 2006. Growth and yield of maize (Zea mays L.) as affected by row spacing and weed competition durations. Journal of Plant Science, 38(4): 27-36.

Ahmad, W., Ahmad, A.U., Zamir H., Afzal M. S. I., Mohsin M., Khalid A. U., and Gillani, S.M.W., 2012. Qualitative and quantitative response of forage maize cultivars to sowing methods under subtropical conditions. The Journal of Animal \& Plant Sciences, 22 (2):318-323.

Aslam, M., Iqbal, A.I., Zamir, M.S., Mubeen, M., and Amin M., 2011. Effect of different nitrogen levels and seed rates on yield and quality of maize fodder. Crop and Environment, 2(2): 47-51.

ATA (Agricultural Transformation Agency)., 2013. Maize Sector Development Strategy (Working Document 
2013-2017), Addis Ababa, Ethiopia.

Bavec, F. and Bavec, M. 2002. Effect of plant population on leaf area index, cob characteristics and grain yield of early maturing maize cultivars. European Journal of Agronomy, 16: 151-159.

CIMMYT, 1988. Farm Agronomic to farmers recommendation. An Economic Training Manaual. Completely revised edition, D.F. Mexico. 51p.

CSA (Central Statistical Agency), 2017. Area and production of major crops. Agricultural sample survey2016/17, private, peasant holdings, Meher season, Statistical Bulletin 584, Addis Ababa, Ethiopia.

Dicu G., Ion V., Horhocea D., Daniel State D., ION N., 2016. Results regarding biomass yield at maize under different plant density and row spacing conditions. AgroLife Sc. J: 5: 2285-5718.

EIAR (Ethiopian Institute of Agricultural Research) 2004. Directory of Released Crop Varieties and their Recommended Cultural Practices, Addis Ababa, Ethiopia.

EIAR (Ethiopian Institute of Agricultural Research). 2008. National Maize Research Project,Current research activities, past achievements and future prospective.

Enujeke, E. C., 2013. Nutrient content of Dry Matter of maize as affected by different levels of fertilizers in Asaba Area of Delta State. Sustainable Agriculture Research, 2(3), 7685.http://dx.doi.org/10.5539/sar.v2n3p76

Eskandarnejada S., Khorasanib SK., Bakhtiaric S., and Heidariand AR., 2013. Effect of row spacing and plant density on yield and yield components of sweet corn varieties. Advance Crop Science, 3(1): 81-88.

FAOSTAT, 2016. Food and Agriculture Organization of the United Nations. Accessed on 20 November,2016.

GenStat, 2012. GenStat Procedure Library Release. $15^{\text {th }}$ edition. VSN International Ltd.

Gomez, K A. and A. A. Gomez. 1984. Statistical Procedures for Agricultural Research. 2nd ed. John Wiley and Sons. New York.

Gozubenli, H., Sener O., Konuskan O., and Kilinc M., 2004. The effect of intra-row spacing on the grain yield and some agronomic characteristics of maize (Zea mays L.) hybrids. Asian Journal of Plant Science, $3(4): 429-432$

Odeleye F. O., \& Odeleye, M. O., 2001. Evaluation of morphological and agronomic characteristics of two exolic and two adapted varieties of tomato (Lycopersicom esculentum) in South West Nigeria. Proceedings of the 19th Annual Conference of HORTSON, (1), 140-145.

Olakojo, S. A., Ogundodede, B. A., \& Kogbe, J. O. S., 1993. Evaluation of Maize (Zea mays) Top crosses in a Rainforest Location. Biose Res. Comm, 11(2), 141-146.

Raouf, S.S., Sedghi, M., and Gholipouri, A., 2009. Effect of population density on yield and yield attributes of maize hybrids. Research Journal of Biological Sciences, 4(4):375-379.

Rosegrant, M.W., S. Msangi, C. Ringler, T.B. Sulser, T. Zhu, S.A. Cline, 2010. International Model for Policy Analysis of Agricultural Commodities and Trade (IMPACT): Model Description. International Food Policy Research Institute: Washington, D.C.

Sangoi, L., 2001. Understanding plant density effects on maize growth and development: an important issue to maximize grain yield. Ciencia Rural. 31(1): 159-168.

Singh A.K., Singh G.R., and Dixit R. S., 1997. Influence of plant population and moisture regimes on nutrient uptake and quality of winter maize (Zea mays). Indian J Agron. 42(1): 107-111.

Tolera, A., Berg, T., and Sundstol, F., 1999. The effect of variety on maize grain and crop residue yield and nutritive value of the Stover. Journal of Animal feed Science and Technology, 79(3), 165-177.

Trinh, Q.K., Pham, S. T., and Christian, W., 2008. Improving of maize yield and profitability through site specific nutrient management (SSNM) and planting density. International Plant Nutrition Institute, Southeast Asia Program, Singapore pp.16: 88-92

Zaffaroni E. and A.A Schneiter, 1991. Sunflower production as influenced by plant type, plant population, and row arrangement. Journal of Agronomy, 83: 113-118.

Zenebe Tsegaw, 2004. Effect of plant population and variety on yield and yield related traits of sorghum (Sorghum bicolar (L.) moench) Under Dire Dawa Condition. MSc Thesis, Haramaya University, Haramaya, Ethiopia. 


\section{APPENDICES}

Appendix Table 1. Mean square values of ANOVA for phenological parameters of maize varieties as affected by inter- and intra-row spacing

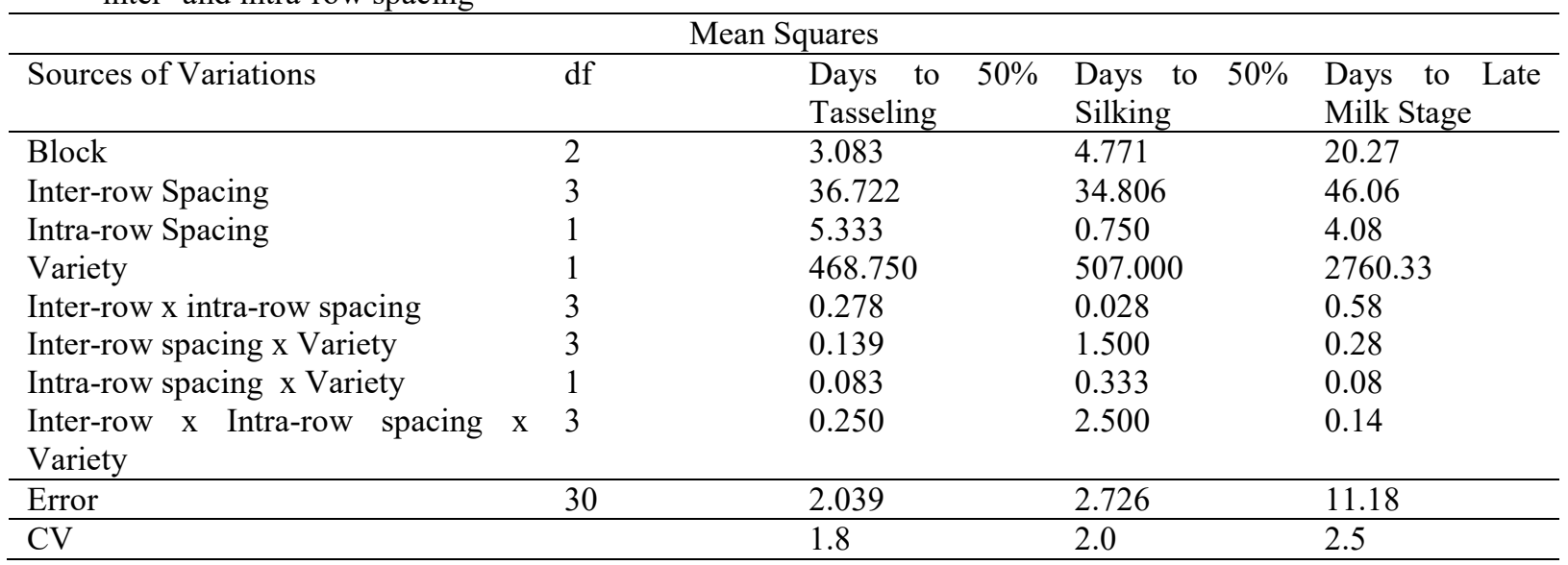

Where $\mathrm{df}=$ Degree of freedom; $\mathrm{CV}=$ Coefficient of Variation

Appendix Table 2. Mean square values of ANOVA for plant height, leaf area and leaf area index of maize varieties as affected by inter-and intra-row spacing

\begin{tabular}{|c|c|c|c|c|}
\hline \multicolumn{5}{|c|}{ Mean Squares } \\
\hline Sources of Variations & df & $\begin{array}{ll}\text { Plant } & \text { Height } \\
(\mathrm{cm}) & \\
\end{array}$ & Leaf Area $(\mathrm{cm} 2)$ & Leaf Area Index \\
\hline Block & 2 & 33.83 & 9458.00 & 0.00466 \\
\hline Inter-row Spacing & 3 & $903.55 * *$ & $1941187.00 * *$ & 2.59250 \\
\hline Intra-row Spacing & 1 & 33.00 & 334167.00 & 3.88754 \\
\hline Variety & 1 & $14008.33 * *$ & $7696809.00 * *$ & 2.08306 \\
\hline Inter-row $\mathrm{x}$ intra-row spacing & 3 & 82.05 & 1875.00 & 0.01416 \\
\hline Inter-row spacing x Variety & 3 & $148.25 * *$ & $200221.00 * *$ & 0.03490 \\
\hline Intra-row spacing $\mathrm{x}$ Variety & 1 & 24.37 & 3763.00 & 0.01998 \\
\hline $\begin{array}{lllll}\text { Inter-row } \mathrm{x} & \text { Intra-row } \\
\text { Variety } & & & & \end{array}$ & 3 & $104.26^{*}$ & 38311.00 & 0.00772 \\
\hline Error & 30 & 27.14 & 31642.00 & 0.01350 \\
\hline $\mathrm{CV}$ & & 2.0 & 2.6 & 3.2 \\
\hline
\end{tabular}

Where $\mathrm{df}=$ Degree of freedom; $\mathrm{CV}=$ Coefficient of Variation; $*$ and $* *=$ significantly different at $5 \%$ and $1 \%$ level of significance

Appendix Table 3. Mean square values of ANOVA for stand count percentage, cob length and cob weight of maize varieties as affected by inter-and intra-row spacing

\begin{tabular}{|c|c|c|c|c|}
\hline \multicolumn{5}{|c|}{ Mean Squares } \\
\hline Sources of Variations & $\mathrm{df}$ & $\begin{array}{l}\text { Stand Count } \\
(\%)\end{array}$ & $\begin{array}{l}\text { Cob Length } \\
(\mathrm{cm})\end{array}$ & Cob Weight (gm) \\
\hline Block & 2 & 1.163 & 1.189 & 1563.000 \\
\hline Inter-row Spacing & 3 & $70.136 * *$ & $31.061 * *$ & 4151.000 \\
\hline Intra-row Spacing & 1 & $22.963 * *$ & 6.021 & 408.000 \\
\hline Variety & 1 & $25.521 * *$ & $339.203 * *$ & 1122.000 \\
\hline Inter-row $\mathrm{x}$ intra-row spacing & 3 & 3.826 & 0.333 & 101.000 \\
\hline Inter-row spacing $\mathrm{x}$ Variety & 3 & 1.870 & $4.714^{*}$ & 26.000 \\
\hline Intra-row spacing $\mathrm{x}$ Variety & 1 & 2.083 & 0.053 & 2.000 \\
\hline Inter-row x Intra-row spacing x Variety & 3 & $5.807^{*}$ & 0.584 & 23.000 \\
\hline Error & 30 & 1.829 & 1.221 & 8533.000 \\
\hline $\mathrm{CV}$ & & 1.4 & 4.4 & 8.6 \\
\hline
\end{tabular}

Where $\mathrm{df}=$ Degree of freedom; $\mathrm{CV}=$ Coefficient of Variation; $*$ and $* *=$ significantly different at $5 \%$ and $1 \%$ level of significance 
Appendix Table 4. Mean square values of ANOVA for number of cobs per plant, number of cobs per hectare and above ground fresh biomass of maize varieties as affected by inter-and intra-row spacing

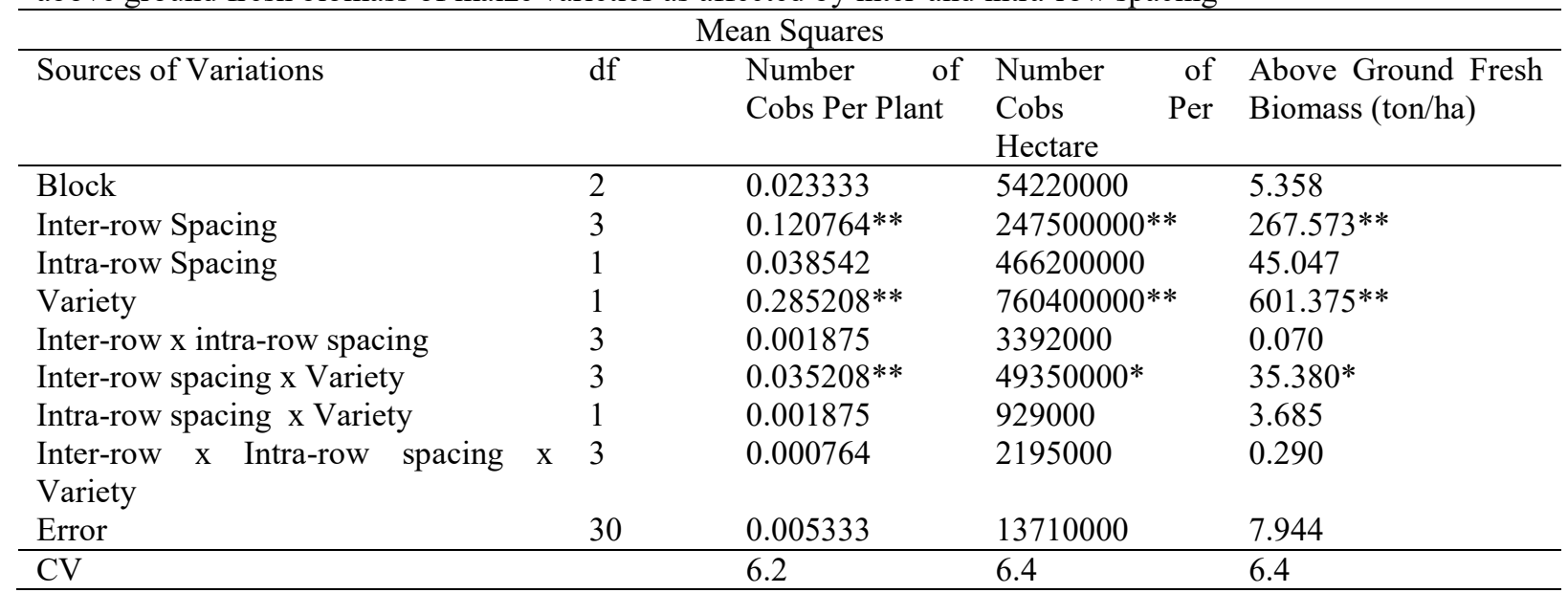

Where $\mathrm{df}=$ Degree of freedom; $\mathrm{CV}=$ Coefficient of Variation; $*$ and $* *=$ significantly different at $5 \%$ and $1 \%$ level of significance 